The Ecology of Invasions by Animals and Plants 


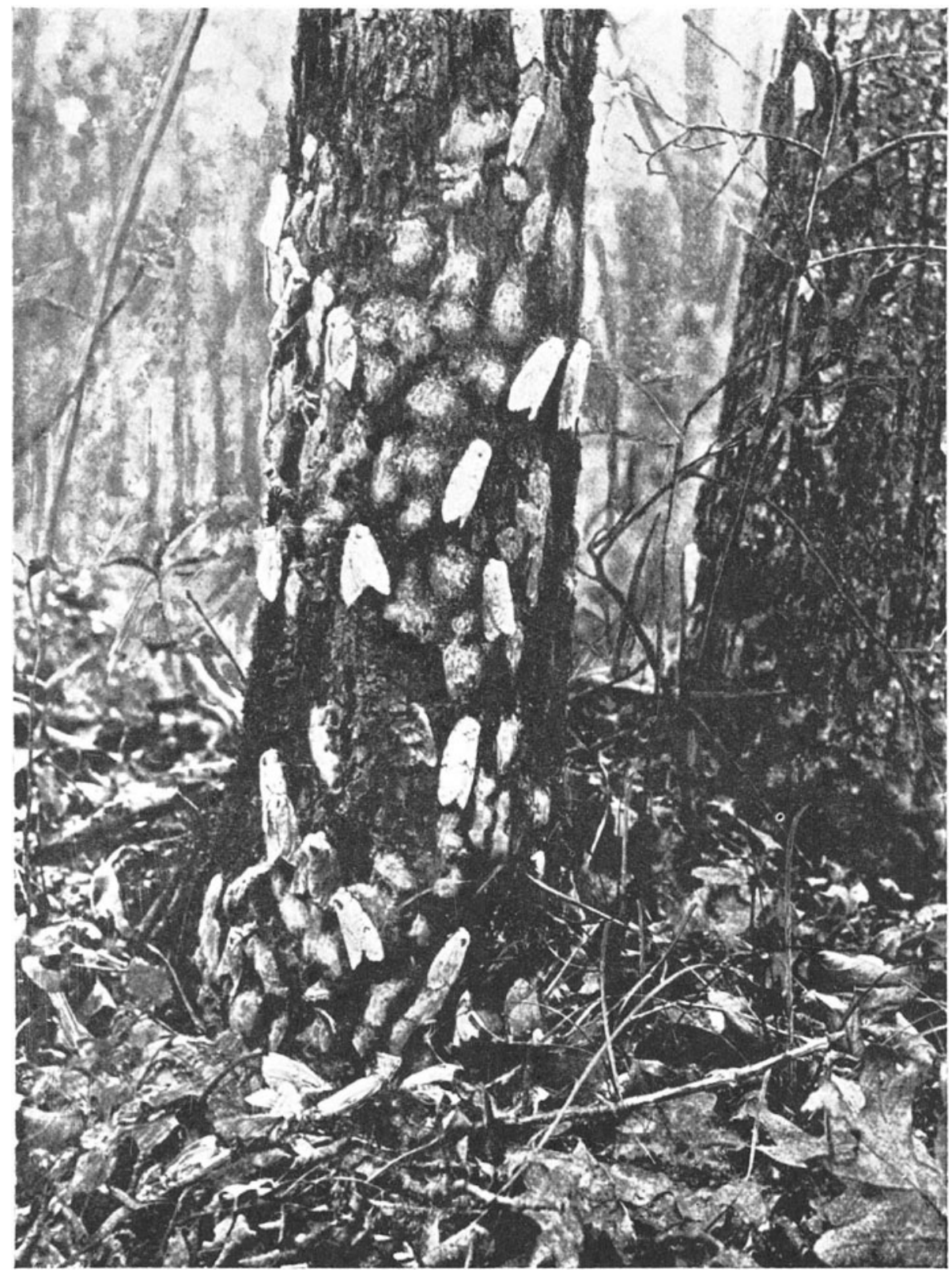

Frontispiece. Female gipsy moths, Lymantria dispar, depositing their egg-clusters on the trunk of an oak-tree in Massachusetts, 1895. (From E. H. Forbush and C. H. Fernald, r896.) 


\section{THE \\ ECOLOGY OF INVASIONS BY ANIMALS AND PLANTS}

\section{CHARLES S. ELTON}

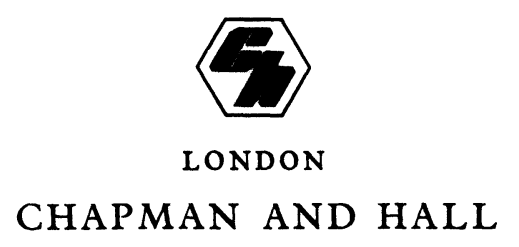


First published 1958

by Methuen $\mathcal{E}$ Co. Ltd.

Reprinted five times

Reprint 1972 published by

Chapman and Hall Ltd, II New Fetter Lane, London EC4P $4 E E$

Reprinted as a Science Paperback 1977

(C) 1958 Charles C. Elton.

Printed and bound in Great Britain by

Redwood Burn Limited

Trowbridge \& Esher

ISBN-13: 978-0-412-21460-8

e-ISBN-13: 978-94-009-5851-7

DOI: $10.1007 / 978-94-009-5851-7$

This paperback edition is

sold subject to the condition that it

shall not, by way of trade or otherwise, be

lent, re-sold, hired out, or otherwise circulated

without the publisher's prior consent in any form of

binding or cover other than that in which it is

published and without a similar condition being imposed

on the subsequent purchaser

All rights reserved. No part of

this book may be reprinted, or reproduced

or utilized in any form or by any electronic, mechanical or other means, now known or hereafter

invented, including photocopying and recording,

or in any information storage or retrieval

system, without permission in writing

from the publisher

Distributed in the U.S.A. by Halsted Press, a Division of Fohn Wiley $\mathcal{E}$ Sons, Inc., New York 
TO MY WIFE

E. J. SCOVELL 


\section{Contents}

PREFACE

I. THE INVADERS

2. WALLACE'S REALMS: THE ARCHIPELAGO OF CONTINENTS

3. THE INVASION OF CONTINENTS

4. THE FATE OF REMOTE ISLANDS

5. CHANGES IN THE SEA

6. THE BALANCE BETWEEN POPULATIONS

7. NEW FOOD-CHAINS FOR OLD

8. THE REASONS FOR CONSERVATION

9. THE CONSERVATION OF VARIETY

REFERENCES

INDEX page I3 


\title{
Illustrations
}

\author{
PLATES
}

Gipsy moths, Lymantria dispar

Frontispiece

[between pages 32 and 33]

I. Dr Karl Meyer explaining methods of field survey for sylvatic plague to public health students

2. Dissecting ground squirrels to obtain organs for plague testing

3. Ground squirrel, Citellus beecheyi: a host of plague in California

4. Mycelial fans of the chestnut blight fungus, Endothia parasitica

5. American chestnut, Castanea dentata, almost killed by Endothia parasitica

$6 \& 7$. Muddy salt-marsh dominated by Spartina townsendii in a tidal inlet on the Sussex coast

8. Muskrats, Ondatra zibethica, at home, New York State

9. Young sea lampreys, Petromyzon marinus, attacking brook trout in an aquarium

10. Male mitten-crab, Eriocheir sinensis

II. Young planktonic stage of the mitten-crab

12. Coypus, Myocastor coypus, at home in South America

13. Habitat of the coypu in an East Anglian broad

[between pages 72 and 73]

14. A forest scene on the Upper Amazon

15. Mammals of the North American prairie

16. Mammals in Western Tartary (Central Asia)

17. A river and forest scene in equatorial West Africa

18. A scene on the plains of New South Wales

19. Birds in a Malay Peninsula forest

20. English elms dying of fungus disease 
ILLUSTRATIONS

21. Destruction of white spruce, Picea glauca, by the European spruce sawfly, Gilpinia hercyniae, in Quebec.

22. A moth, Aphomia gularis, of stored products, recently spread from the Orient

\section{[between pages I04 and 105]}

23. Statues on Easter Island

24. Grassy slopes of an old crater on Easter Island, with statues

25. Snails and weevil from Easter Island

26. Hawaiian land snails, Achatinella and Amastra, damaged by introduced rats

27. The Ou, Psittacirostra psittacea, a Drepanid bird evolved in the Hawaiian Islands

28. Giant African snails, Achatina

29. Distribution of introduced pheasants in the Hawaiian Islands

30. Southern beech, Nothofagus, forest in New Zealand, inhabited by introduced red deer, Cervus elephas, and Australian opossum, Trichosurus

31. Hawaiian rats, Rattus hawaiiensis

32. Introduced American whelk tingle, Urosalpinx cinerea, on English oyster

33. American slipper limpets, Crepidula, being cleared from derelict English oyster beds

34. Striped bass, Roccus saxatilis, caught by an angler in California

35. A striped bass being tagged in California, to study its migrations

36. Slaughtered cattle being buried, during a successful campaign against foot-and-mouth disease in California

37. DDT dusting during an eradication campaign against the Colorado potato beetle in England

[between pages 144 and I45]

38. Old wallow of the American bison on the high plains of Kansas, I 899

39. Huge stack of skulls of the American bison in Saskatchewan, 1890

40 \& 41. Topsoil erosion in a farm area in southern Ontario, with recolonization by planted vegetation

42. Fluted scale insect, Icerya purchasi, attacked by the ladybird Novius cardinalis, on a Californian citrus tree 


\section{ILIUSTRATIONS}

43. Reproduction and mortality: a Tachinid fly parasite, Centeter cinerea, attacking pairing Japanese beetles, Popillia japonica

44. Gonaxias, a predatory snail, on the giant African snail, Achatina fulica

45. A lane in Oxfordshire in May

46. A Hampshire roadside in June

47. Hedgerow oak trees, used for timber, along a Hampshire roadside

48. Aerial view of contour terraces and hedges, established on an Indiana farm area to check soil erosion

49. Hedges of flowering Rosa multiflora on a farm in Maryland

50. The pattern of field, hedgerow, and woods seen from the Malvern Hills

\section{FIGURES IN THE TEXT}

I \& 2. Areas in the United States where plague in man and rodents had occurred, 1900-5I

3. Distribution of the African malaria mosquito, Anopheles gambiae, in Brazil, 1938-40

4. Spread of the Asiatic chestnut fungus, Endothia parasitica, to American chestnuts, Castanea dentata, up to I9I I

5. Spread of the European starling, Sturnus vulgaris, in the United States and Canada, up to 1926

6. Distribution of the North American muskrat, Ondatra zibethica, in Europe and Asia

7. Spread of the muskrat in Central Europe, 1905-27 25

8. Spread of the muskrat in France, up to 1954

9. Spread of the Chinese mitten-crab, Eriocheir sinensis, in Europe, I912-43

10. Map of the broken Isthmus of Panama in Tertiary times

II. Distribution of an Australasian family of birds, the cockatoos, westwards to Wallace's Line

12. Distribution of a woodpecker, Dryobates moluccensis, west of Wallace's Line and in the Sunda Islands

13. Distribution of some Australasian genera of animals in the Malay Archipelago and western New Guinea islands 


\section{ILLUSTRATIONS}

14. Spread of the Japanese beetle, Popillia japonica, in the United States, 1916-23

15. Spread of the Japanese beetle, Popillia japonica, in the United States, I9I6-4I

16. Distribution of the Argentine ant, Iridomyrmex humilis, in the United States, up to 1936

17. Distribution of the Colorado beetle, Leptinotarsa decemlineata, in Europe up to 1956

18. Natural distribution of the Colorado beetle in North America

19. Spread of the Colorado beetle to cultivated potatoes in North America

20-5. The breakdown of Wallace's Realms by insect pests:

20. Distribution of the Japanese beetle, Popillia japonica

21. Distribution of the European spruce sawfly, Gilpinia hercyniae

22. Distribution of the Colorado beetle, Leptinotarsa decemlineata

23. Distribution of the lucerne 'flea', Sminthurus viridis

24. Distribution of the small cabbage white butterfly, Pieris rapae

25. Distribution of the fluted scale insect, Icerya purchasi

26. Spread of the winter moth, Operophtera brumata, in Nova Scotia

27. Spread of the felted beech scale insect, Cryptococcus fagi, in Canada

28. Spread of the elm bark-beetle, Soolytus multistriatus, and the elm fungus disease in North America, up to 1937

29. Distribution of the European spruce sawfly, Gilpinia hercyniae, in North America, 1938

30. Distribution of the European spruce sawfly, Gilpinia hercyniae, in Canada, 1942

3I. Distribution of a moth, Aphomia gularis, of stored products, recently spread from the Orient

32. Distribution of the topminnow or mosquitofish, Gambusia affinis, over the world 


\section{ILLUSTRATIONS}

33. Introduced birds and mammals of New Zealand, with their countries of origin

34. Distribution of the introduced red deer, Cervus elaphus. in the North Island of New Zealand, 1947

35. Distribution of the introduced red deer, Cervus elaphus, in the South Island of New Zealand, 1947

36. Falkenbergia rufolanosa, an Australasian seaweed recently spread to Europe and North Africa

37. Distribution of Falkenbergia rufolanosa and its other phase Asparagopsis armata in Europe and North Africa

38. Distribution of the American whelk tingle, Urosalpinx cinerea, in English oyster beds

39. Distribution of the Pacific quinnat salmon, Onchorhynchus tschawytscha, in New Zealand

40. Distribution of the gipsy moth, Lymantria dispar

4I. Spread of the gipsy moth in the eastern United States

42. Invasion by the American muskrat, Ondatra zibethica, in Shropshire, England, up to 1933

43. Population maps of the English oyster, Ostrea edulis, and the introduced American slipper limpet, Crepidula, in an oyster bed

44. Spread of the black grain stem sawfly, Cephus tabidus, in the eastern United States

45. Mutually exclusive distribution of the stem sawflies, Cephus pygmaeus and C. tabidus, in the eastern United States

46. Peter Breughel's picture: 'The big fish eat the small ones'

47. Distribution of the introduced reindeer in Alaska in 1930-8 and in 1952

48. Natural distribution of the genus Rhododendron

49. Distribution in Britain of an introduced Tingid bug, Stephanitis rhododendri, that damages rhododendron leaves

50. A longicorn beetle, Tetropium gabrieli, whose larvae damage larch

51. Distribution of Tetropium gabrieli and its host tree, the larch 


\section{Preface}

Tn this book I have tried to bring together ideas from three different streams of thought with which I have been closely concerned during 1 the last thirty years or so. The first is faunal history, usually regarded as a purely academic subject, but to some of whose events can be traced a number of the serious dislocations taking place in the world today. The second is ecology, particularly the structure and dynamics of populations. The third is conservation. I first published a few ideas about the significance of invasions in 1943, in a war-time review called Polish Science and Learning, under the title of 'The changing realms of animal life'. Since then I have had the opportunity to think pretty hard about conservation, while taking part in the planning and development of the Nature Conservancy. In March 1957 I gave three broadcasts in the B.B.C.'s Third Programme, under the title of 'Balance and Barrier'. These were subsequently printed in The Listener (1957, Vol. 57, pp. 514-1 5, 556-7, 596-7, and 600). The present book is essentially an expansion of these. I am extremely grateful to Mr James C. Thornton and Dr John Simons for advice and help in planning and giving these talks.

In preparing this book I have had invaluable assistance from the staff of the Bureau of Animal Population. Miss C. M. Gibbs typed the fair copy. Miss $M$. Nicholls has given me much advice on bibliographical matters. And Mr Denys Kempson has employed his superlative skill at photography in copying and printing the ror illustrations. Without his help particularly I could not have made the book in its present form.

For permission to reproduce illustrations I am very grateful to a number of people and institutions, who are individually acknowledged in the legends under them. I want to thank Mrs M. J. Thornton and $\mathrm{Mr}$ J. S. Watson very much for allowing me the use of original photographs. The following have given invaluable help in getting me the use of other unpublished photographs: Dr Paul DeBach, Citrus Experiment 
Station, University of California; Mr F. H. Jacob, Plant Pathology Laboratory, Ministry of Agriculture, Fisheries and Food; Dr R. F. Morris, Forest Biology Laboratory, Science Service, Canadian Department of Agriculture; Miss P. Sichel, National Maritime Museum, Greenwich; Dr Edward Graham and Dr William Van Dersal, U.S. Soil Conservation Service.

I am obliged to Dr W. E. Swinton, British Museum (Natural History), for some information about dinosaurs, and to Dr Erling Christophersen for information about plant species on Tristan da Cunha.

I have found useful references in a paper by Marston Bates (1956), 'Man as an agent in the spread of organisms' (in Man's role in changing the face of the earth, ed. by W. L. Thomas and others, Chicago, pp. 788804). This is the only recent general review of the subject of invasions that I have seen.

The life-group pictures in Chapter 2, borrowed from Alfred Russel Wallace's great book The Geographical Distribution of Animals, are included not only for their own merit, but because I discovered that only two members of a large class of advanced zoology students had ever read the book. I have kept his Latin names without any attempt to bring them up to date, but have only used the genera and not the species.

I am grateful to my wife for reading the whole of this book before publication and for making most valuable suggestions.

Bureau of Animal Population,

Department of Zoological Field Studies,

Botanic Garden, Oxford.

24 Fuly 1957 